\title{
THE POTENTIAL OF LITERARY TEXTS IN THE LANGUAGE CLASSROOM: THE STUDY OF LINGUISTIC FUNCTIONS ${ }^{1}$
}

\author{
Purificación Sánchez Hernández, Universidad de Murcia \\ Email: purisan@um.es
}

\begin{abstract}
Communication in a second language is a type of achievement which requires a very functional use of the language, resulting in the students' ability to express needs, desires, feelings and attitudes. Both oral and written communication should be immediate and onging from the point when students start studying a language and should provide them with a sense of progress in the foreign language. In order to achieve effective and motivating communication, it is usually necessary to go beyond the forms of the language or to use other input which differ from the traditional coursebook. In this sense, literary texts present a never-ending source of resources for studying and communicating in a foreign language.

This paper presents an integrated approach to the study of language and literature, highlighting the potential of literary texts when studying the characteristics of a language and paying special attention to how linguistic functions can be explored, studied and practiced through literary texts.
\end{abstract}

Keywords: linguistic functions, literature, language.

Título en español: El potencial de los textos literarios en el aula de idioma: Estudio de las funciones lingüísticas.

Resumen: La comunicación en una lengua extranjera requiere un uso funcional de la lengua, lo que da como resultado la capacidad de los estudiantes para expresar deseos, necesidades, sentimientos y actitudes. Tanto la comunicación oral como la escrita deben ser inmediatas desde el momento en que se comienza a estudiar una lengua y deberían proporcionar al usuario una sensación de progreso en la lengua extranjera. Para lograr una comunicación efectiva y motivadora, es necesario ir más allá de las formas de la lengua o utilizar materiales diferentes del libro de texto. En este sentido, los textos literarios presentan una fuente inagotable de recursos para estudiar y comunicarse en una lengua extranjera.

En este trabajo se presenta un enfoque integrado para el estudio de la lengua y la literatura, poniendo de manifiesto el potencial de los textos literarios para explorar las características del lenguaje y prestando especial atención a la exploración, estudio y práctica de las funciones lingüísticas a través de los textos literarios.

Palabras clave: funciones lingüísticas, literatura, lengua.

Date of reception: 15 June 2011

Date of acceptance: 15 September 2011 


\section{INTRODUCTION}

Methods and approaches such as Grammar Translation, Audiolingualism and Situational Language Teaching, essentially grammar-based syllabuses, are based on the presentation and practice of grammatical structures. In 1972, the British linguist D.A. Wilkins published a document proposing a radical shift away from using the traditional concepts of grammar and vocabulary to describe language to an analysis of the communicative meanings that learners would need in order to express themselves and to understand effectively. This initial document was followed by his 1976 work Notional Syllabuses, which showed how language could be categorized on the basis of notions such as quantity, location and time, and functions such as making requests, making offers and apologizing (Finocchiaro \& Brumfit 1983).

Based on Wilkins proposals (1972), notional-functional syllabuses started with the work of the Council of Europe (Van Ek and Alexander 1975) and approached functions as organizing elements of a foreign language curriculum. The "functional" component of the notional-functional syllabuses corresponded to language functions, interpreting a function as some kind of communicative act: the use of language to achieve a purpose, usually involving interaction between at least two people. Examples of this would be suggesting, promising, apologizing, greeting or inviting.

Generally speaking, people who study and use a language are mainly interested in how they can do things with language - how they can make meanings, get attention to their problems and interests, influence their friends and colleagues and create a social life for themselves (Collins Cobuild 1990). Not everybody is interested in the grammatical structure of language as a means to communicate. The "Functional Approach" refers to an approach to syllabus design, not a method of language teaching. It restructures the presentation of the target language to coincide with the communicative functions or use to which the language will be put.

A functional syllabus is based on learning to recognize and express the communicative functions of language and the concepts and ideas it expresses. This type of syllabus is based more on the purposes for which language is used and on the meanings the speaker wanted to express than on the forms used to express them. Some of the benefits students get from these syllabuses are: a) Learners learn how to use language to express authentic communicative purposes, and b) Learners may be motivated by the opportunity to use language to express their own purposes, ideas and emotions.

Despite the controversy over their effectiveness, at present, typical modern-day language textbooks will list a sequence of communicative functions that are covered and vary depending on the level for which the books have been designed. The publications made to specify the goals that should be attained to reach a certain language level present exhaustive lists of functions, notions, vocabulary areas, and grammar areas. Achieving communicative competence involves acquiring knowledge of the forms and functions of a language. 


\section{THE ROLE OF LITERATURE IN THE LANGUAGE CLASSROOM}

The relationship between literature and language has changed according to the paradigm applied to the teaching of language, particularly in the last century. The relationship was an excellent one at the beginning of the 20th century under the classical paradigm when "literary language was superior to spoken language" (Larsen-Freeman 2000: 15). Literature was then left out of language programs because language learning consisted first and foremost of speech, of habit formation, or of transmitting what one knows in new contexts, depending on the learning paradigm used. With the development of communicative approaches to language learning, the goal of language learning was to encourage communicative competence in the target language, where students would have the opportunity to express their ideas and opinions in the language under study; the emphasis should be on the process of communication rather than just mastery of language forms (Larsen-Freeman 2000). Literature has experienced a revival with the advent of communicative approach in language teaching as it provides learners with authentic, pleasurable and cultural material (Hall 2005: 47-57).

According to Savvidou (2004), Duff and Maley (1990) suggest that the main reasons for integrating literary texts in the language classroom are linguistic, methodological and motivational. Linguistically, by using a wide range of authentic texts we introduce learners to a variety of types and difficulties of English language. Methodologically, literary discourse sensitises readers to the processes of reading e.g. the use of schema, strategies for intensive and extensive reading etc. And, lastly, motivationally, literary texts prioritise the enjoyment of reading since, as Short and Candlin state (1986: 90), 'if literature is worth teaching qua literature, then it seems axiomatic that it is the response to literature itself which is important'. An integrated model is a linguistic approach that involves the systematic and detailed analysis of the stylistic features of a text - vocabulary, structure, register - in order to find out 'not just what a text means, but also how it comes to mean what it does' (Short, 1996).

The potential benefits of using literary texts in the language classroom have been widely discussed (Maley and Duff, 1989; Carter et al., 1989; Widdowson, 1992; Kramsch, 1993; Lazar, 1993; Carter and McRae, 1996; Edmonson, 1997). Gilroy and Parkinson (1997), Belcher and Hirvela (2000), Yang (2001), Vandrick (2003), Kim (2004) and Sánchez (2008) discuss how to use literature to teach English as a foreign language. Schröder (1977), Keunen and Eeckhouf (2001), Denka (2005) and Hall (2005) focus on the position of literature in foreign language teaching. Parkinson and Reid Thomas (2000: 9-11) highlight the role of literature in providing an excellent model for good writing: it is memorable, non-trivial and challenging, and it also helps assimilate the rhythms of a language, therefore facilitating intelligence and sensibility training. Parkinson and Reid Thomas (2000), Carter and Stockwell (2008) and Paran (2008) present comprehensive and accurate reports on the state of the matter.

It is generally agreed (Maley, 2001) that literary texts seem to be an ideal tool both for developing literary comprehension and sensibility and also to enhance the communicative skills of the language: literary texts supply examples of authentic language, provide lots of opportunities for the expression of ideas, opinions, and beliefs and are a springboard 
for any writing activity. Furthermore, literature helps enhance the psycholinguistic aspect of language learning as it focuses on form and discourse processing skills and improves vocabulary expansion and reading skills. The text seems to be the perfect vehicle to investigate the stylistic features of an author and the characteristics of a period. However, texts can also be explored at different levels: they can present information about culture and society and may be analysed with different purposes (Sánchez, 2008).

\section{RATIONALE FOR THE EXPLOITATION OF LINGUISTIC FUNCTIONS IN LITE- RARY TEXTS}

The idea of presenting the functions of language in literary texts arose when I had to teach a course of Language and Literature to students in their first and second years at university. The secondary school curriculum in Spain includes the study of Spanish literature. Thus, the students who were likely to enrol in the module had been previously exposed to literary works, literary criticism and appreciation. However, the study of the literature of a foreign language is not part of the primary and secondary education syllabuses in our country and, in addition, foreign language and literature have traditionally been taught separately. The lack of appreciation for literature, in general, due to traditional teaching methods which are usually teacher-centred and the stigma attached to it as being a difficult, uninteresting and, in the opinion of many students, a useless area of study, also results in the students' further drawing themselves away from the literature.

Students in the first and second year of their French degree had to study a compulsory 6 credit module of English Language and Literature which lasted a semester and had 4 contact hours per week. Generally, most of the teachers of these modules, with full consent from their students, have mainly focused on the study of the foreign language, leaving literature out or studying it in its conventional form: historical periods, authors and works. In any case, language and literature have always been two separate worlds.

In order to identify the needs, motivations and interests of my students, I handed out a questionnaire at the beginning of the module. The feedback showed that all of them had enrolled in the course with the idea of improving their command of the English language. Despite the fact that the course was devised by the university as a course for beginners, I also learnt that they were not beginners. Most of them had studied English Language at school which is why I should offer them "something different" to the way they have been taught English language so far as well as to comply with the University's regulations and to make sure that the students remain interested despite the low language level of the module. Although literature is an important component of the program (50\%), the students registered on the course were more inclined to develop their language skills. Some of them manifested no interest in learning English literature while others were clearly reluctant to study literature and, in particular, analyse literary texts. I had a challenge ahead of me and I decided to present my students with a syllabus which would integrate the study of language and literature because I firmly believe in the power of literature when it comes to learning a language and improving the communicative competence of my students. I also wanted to a) broaden students' horizons by giving them a knowledge of the classics of English literature, b) improve students' general cultural awareness, c) stimulate students' creative 
and literary imagination and to develop their apprecition of literature, and d) introduce students to masterpieces in British Literature (Akyel \& Yalcin, 1990: 175).

The students were informed in the first session that the module's program included the study of literary texts so as to comply with the requirements of the syllabus programed in advance and to also make the most of them to underline some of the linguistic aspects of the literary text. The aim was to make the learning of language and literature attractive to each and every student and to offer a different approach to the conventional teacher-centred one. The focus of the learning process should be on the student, which, apart from being a desirable practice in language teaching, is also one of the goals of the Bologna parameters which Spanish universities are adapting to at present. I expected my students to reflect on the language present in the literary texts thus stressing the potential of literary texts not only under a literary, cultural or personal growth model (Carter and McRae, 1996) but also to help them learn more language, more about the language and more with the language.

\section{DESIGN OF THE MODULE}

My purpose was twofold: on the one hand improve the communicative competence of my students, and on the other hand build on their knowledge of English Literature. In order to increase the students' linguistic competence, I devoted my attention to particular components of language (vocabulary, morphosintaxis, phonological components), to communicative skills (reading and listening comprehension, and writing and speaking), and also to the communicative functions of the language. With regard to the learning of the English language, I organised the syllabus so that the needs of both the system and the communicative functions it is used for are kept in some kind of balance. As for the study of English grammar, I started with what I felt the learner could manage without excessive effort and which wouldn't damage his or her confidence. These entry points should be structures such as "I am..." or "I live in...", not only because they are easy but because they are useful. They provide the learners with elemental knowledge of the language and when used correctly the learner has the feeling of having accomplished an important task.

It is generally claimed that students feel more confident if they have a coursebook to follow (Thanasoulas, 1999), even the most proficient students. That is why for the study of the English language I selected a coursebook appropriate for the students' level with a syllabus made up of functions, grammar and vocabulary. Each English language unit was presented with an introductory theme, composed of diverse topics where the different functions of the language were studied. Grammar and vocabulary were presented in context and all the skills were practiced from the very beginning. The study of the components and skills of the language as well as the linguistic functions provided the students with the know-how, techniques and resources necessary for the exploitation of the literary texts.

Most new coursebooks contain some kind of functional syllabus alongside a focus on grammar and vocabulary, thus providing learners with communicatively useful expressions together with a structured syllabus with a clear sense of progression. Working with syllabuses where the functions of the language are presented, studied and practiced, provide the basis for organizing courses and materials mainly for the following reasons: 1) They reflect a more comprehensive view of language than grammar syllabuses and focus on the use of 
the language rather than the linguistic form; 2) They can readily be linked to other types of syllabus content (e.g. topics, grammar, vocabulary); 3) They also provide a convenient framework for the design of teaching materials, particularly in the domains of listening and speaking.

For the study of literature I prepared some concise written information on the most important periods of English Literature as well as on the most relevant authors from these periods. To reach my final objective, I selected literary texts that, besides representing the author and literary period under study, could also be studied in terms of the language grammar and functions presented in the text, which have previously been studied as part of their English grammar program and were, therefore, of relevance to the students' language level. My assumption, according to Berns (1984), is that context is the real key to giving meaning to both form and function, and therefore just because a function is covered in the coursebook does not mean that learners have internalised it for authentic, unrehearsed use in the real world. "Communication is qualitative and infinite; a syllabus is quantitative and finite” (Douglas Brown, 2000: 253).

The last stage was the selection of the texts: they should be relevant to the author's works, representative of the period, and the texts should present some linguistic functions in line with the level of English they were studying. In addition, the vocabulary and grammar structures in the text should be likely to be used by the students both in their written and oral production. I put together a list of the linguistic functions from the English language coursebook which needed to be explored in the literary texts, establishing a progression from the most simple ones to those which make use of more complex grammar forms. It was a difficult task to analyse the texts that could meet all the objectives I had in mind, especially when I had to adapt to the scheme presented in the English language coursebook and explain English Literature from a chronological point of view. All the texts selected were accompanied by a series of exercises to explore vocabulary, grammar and linguistic functions, trying to keep a balance between form and function. They were designed under the scheme of pre-reading, while-reading and post-reading with the aim of getting the most out of the text from a literary and linguistic point of view, assuming that literary texts are an ideal tool for developing literary comprehension and sensibility and for enhancing the communicative skills in a language: literary texts supply examples of authentic language, provide lots of opportunities for the expression of ideas, opinions, and beliefs and are a springboard for any writing activity (Maley, 2001). In the end students' opportunities for learning and knowing are crucially dependent on the nature of the activities in which they engage and on the functions that language performs in these activities (Nuthall and Alton-Lee, 1995).

I then organized 14 units for the 14 teaching weeks of the semester to present and practice situations, vocabulary, grammar forms and linguistic functions of the coursebook.

\section{DESCRIPTION AND PERFORMANCE OF THE UNITS}

When designing the 14 units I made a schema of the situations, functions, grammar and vocabulary to be presented and used in the language lesson. As for the study of the literature syllabus, I designed the theoretical component together with a text corresponding 
to the period under study, with some exercises to highlight and practice the same language functions presented in the language section.

To illustrate my point, I present here the design of the first unit for both language and literature.

\begin{tabular}{|c|c|c|c|c|c|}
\hline $1 \mathrm{a}$ & $\begin{array}{l}\text { The Interna- } \\
\text { tional Lan- } \\
\text { guage. }\end{array}$ & $\begin{array}{l}\text { At the library } \\
\text { At the recep- } \\
\text { tion desk } \\
\text { In the confer- } \\
\text { ence room } \\
\text { Where is he/ } \\
\text { she from? }\end{array}$ & $\begin{array}{l}\text { Identifying. } \\
\text { Asking for in- } \\
\text { formation and } \\
\text { for confirmation } \\
1 . \\
\text { Greeting peo- } \\
\text { ple. } \\
\text { In tro d u c ing } \\
\text { someone. } \\
\text { Seeking identi- } \\
\text { fication. } \\
\text { A n s w e r i n g } \\
\text { questions, for } \\
\text { confirmation, } \\
\text { for information } \\
\text { 1. } \\
\text { Asking for con- } \\
\text { firmation } \\
\text { understanding, } \\
\text { asking to spell } \\
\text { something. } \\
\text { Skills involved: } \\
\text { reading, listen- } \\
\text { ing, writing and } \\
\text { speaking. }\end{array}$ & $\begin{array}{l}\text { Present tense } \\
\text { "To Be" } \\
\text { Affirmative } \\
\text { and negative } \\
\text { forms } \\
\text { Short answers } \\
\text { Word order in } \\
\text { questions } \\
\text { Adjectives } \\
\text { Imperatives } \\
\text { Possessive ad- } \\
\text { jectives } \\
\text { Capital letters }\end{array}$ & $\begin{array}{l}\text { Countries } \\
\text { Nationalities } \\
\text { Days of the } \\
\text { week } \\
\text { Numbers 1-10 } \\
\text { Personal pro- } \\
\text { nouns } \\
\text { Verbs: ask, lis- } \\
\text { ten, look, read, } \\
\text { spell, write } \\
\text { How, } \\
\text { when, where } \\
\text { Prepositions: in, } \\
\text { for, from }\end{array}$ \\
\hline $\begin{array}{l}1 \quad b \\
\text { Lit- } \\
\text { era- } \\
\text { ture }\end{array}$ & $\begin{array}{l}\text {-Theory: } \\
\text { I. Anglo-Sax- } \\
\text { on Literature } \\
\text { (c. 600-1066) } \\
\text { General intro- } \\
\text { duction: } \\
\text { Characteristics } \\
\text { of Anglo-Sax- } \\
\text { on Poetry } \\
\text { Beowulf and } \\
\text { The Battle of } \\
\text { Maldom. } \\
\text {-Practice: } \\
\text { C.P.1. Anglo- } \\
\text { Saxon Poetry }\end{array}$ & $\begin{array}{l}\text { Beowulf } \\
\text { Beowulf an- } \\
\text { nounces his } \\
\text { home. } \\
\text { Thegreathero } \\
\text { announces } \\
\text { himself and } \\
\text { explains his } \\
\text { mission }\end{array}$ & $\begin{array}{l}\text { Introd ucing } \\
\text { someone. } \\
\text { Asking ques- } \\
\text { tions for infor- } \\
\text { mation. } \\
\text { A n s w e r i n g } \\
\text { questions for in- } \\
\text { formation. }\end{array}$ & . & $\begin{array}{l}\text { Terms used to } \\
\text { introduce one- } \\
\text { self (birth) } \\
\text { Terms related } \\
\text { to war (kill, } \\
\text { leader) }\end{array}$ \\
\hline
\end{tabular}

Table 1. Design of the first unit. 
Each text was presented to the students with some exercises (7-8) aimed at developing their understanding of the linguistic and literary aspects of the selected excerpt. In the case of the unit presented above one of the exercises, related to the use of linguistic functions, was as follows:

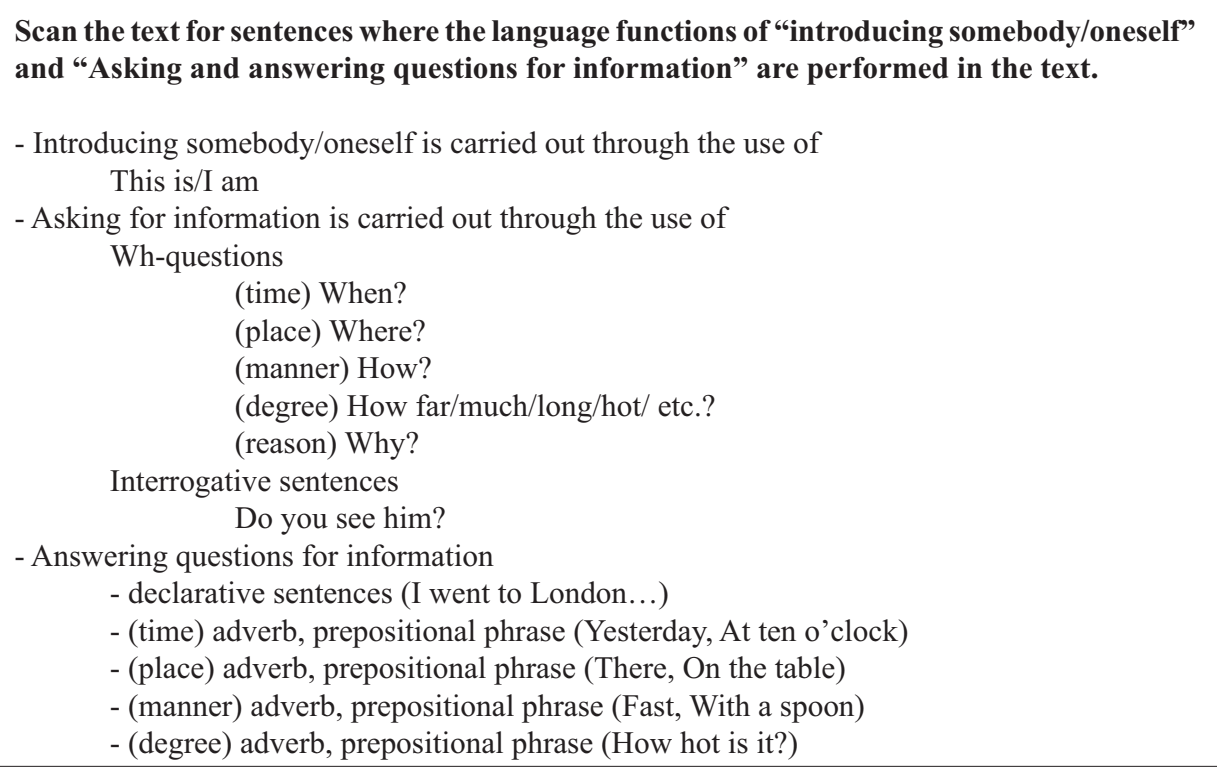

Table 2. Exercise to practice linguistic functions.

The exercise came with some information on how the functions of the language were to be performed, thus helping students remember and identify the functions under study. However, it is not enough just to know something: it is necessary to practice the structures once they have been presented to the students. To help them use and "learn" the linguistic functions of introducing oneself, the last exercise of the unit was to "Write a composition introducing yourself and stating your intention when enrolling in this course". They were asked to write a piece of text introducing themselves and explaining their "mission" in terms of their motivations and interests which led to them enrolling in this module. This way they could automatically practice the functions they have studied throughout the unit as well as the other linguistic features of the text. The oral and written exercises which were used to explore the literary texts promoted communication between the students and the teacher and among the students themselves, and helped develop cognitive activity and not merely the rehearsal and eventual acquisition of linguistic forms (Brooks and Donato, 1994: 13)

\section{DISCUSSION AND CONCLUSION}

One of the main criticisms of functional approaches is the difficulty in deciding the order in which different functions should be presented since there are no clear criteria for selecting or grading functions. Schaeffer (1982) proposed that the teachable parts of the 
functions be sequenced in approximately the same order that they appear in the speech. In this paper I have adapted to the way in which functions are presented in the coursebook associated to situations. By following the sequence adopted in the book, I reinforced what the students were learning in the language class by presenting the functions, starting with the most elementary ones - those deemed most necessary in order to elicit conversation to more complex linguistic functions, thus keeping a balance between the order in which the functions were presented in the coursebook and the functions to be exploited in the literary texts.

Nunan (1998) suggests that decisions about which items to include in the syllabus should be made to help learners carry out the communicative purposes for which they need the language. Widdowson (cited in Nunan, 1998) argues that dividing language into discrete units of whatever type misrepresents the nature of language as communication. Syllabuses based on linguistic functions represent a simplistic view of communicative competence and fail to address the processes of communication. This may happen if we work with a syllabus based on linguistic functions. However, this was not our case since we also paid attention to the study of grammar and vocabulary in context, thus avoiding another of the potential drawbacks of studying a functional syllabus: the gaps that students learning from a functional course may have in their grammatical competence because some important grammatical structures may not be elicited by the functions that are taught in the syllabus.

Integrating literature into foreign language teaching paves the way for equipping students with a number of skills including the development of critical thinking, analytical skills, formulating and expressing independent opinions, presenting one's own interpretations independently, and understanding and improving language competence.

This paper discusses the importance and challenge of integrating literary texts into the study of language and proposes a novel and integrated approach to the study of language and literature stressing the benefits of using literary texts to explore the characteristics of a language and showing how the linguistic functions of a language can be studied and practised through literary texts.

\section{REFERENCES}

Akyel, A., \& Yalcin, E. 1990. "Literature in the EFL class: a study of goalachievement incongruence", ELT Journal, 44/3: 174-180.

Belcher, D., and Hirvela, A. 2000. Literature and L2 composition: Revisiting the debate. Journal of Second Language Writing, 9(1), 21-29.

Berns, M. S. 1984. Review of Finocchiaro and Brumfit 1983. TESOL Quarterly, 18: 325-329.

Brooks, F., And Donato, R. 1994. Vygotskyan Approaches to Understanding Foreign Language Learner Discourse during Communicative Tasks. Hispania, 77, 2, 1-16.

CARTER, R.A., AND McRAE, J. eds. 1996. Language, Literature and the Learner: Creative Classroom Practice. London: Longman. 
Carter, R. A. and Stockwell, P. 2008. The Language and Literature Reader. London: Routledge.

CARTER, R.A., WALker, R., AND Brumfit, C.J. eds. 1989. Literature and the Learner: Methodological Approaches. ELT Documents 130. London: Modern English Publications/Macmillan/The British Council.

Collins Cobuild English Grammar, 1990. London: Collins

DENKA, A. 2005. Lesestrategien und lesesteuerungsstrategien beim einsatz literarische texte im fremdsprachenunterricht. Lang: Frankfurt am Main.

Douglas B. H. 2000. Principles of Language Learning and Teaching. New York: Longman.

Duff, A. And Maley, A. 1990. Literature. London: OUP.

EDMOnson, W. 1997. The role of literature in foreign language learning and teaching: some valid assumptions and invalid arguments. AILA Review No. 12: Applied Linguistics Across Disciplines: 42-55.

FinOcChiaro, M., AND Brumfit, C. 1983. The Functional-Notional Approach. New York, NY: Oxford University Press.

GiLroy, M., AND PARKINSON, B. 1997. Teaching literature in a foreign language. Language Teaching, 29(4), 213-225.

HaLl, G. 2005. Literature in language education. Palgrave Macmillan: New York.

Keunen, B. And Eeckhouf, B. eds. 2001. Literature and society. Lang: Bruxelles.

KIM, M. 2004. Literature discussions in adult L2 learning. Language and Education, 18(2), 145-166.

Kramsch, C. J. 1993. Context and Culture in Language Teaching. Oxford: OUP.

LARSEN-Freeman, D. 2000. Techniques and Principles in Language Teaching. Oxford: OUP.

LAZAR, G. 1993. Literature and Language Teaching: A Guide for Teachers and Trainers. Cambridge: CUP.

Maley, A. 2001. Literature in the Language Classroom. In R. Carter, and D. Nunan, The Cambridge Guide to Teaching English to Speakers of Other Languages. Cambridge: CUP.

Maley, A., AND Duff, A. 1989. The Inward Ear: Poetry in the Language Classroom. Cambridge: Cambridge University Press.

Nunan D. 1988. Syllabus Design. Oxford: Oxford University Press.

Nuthall, G., And Alton-Lee, A. 1995. “Assessing Classroom Learning: How students use their knowledge and experience to answer classroom achievement test questions in science and social studies." American Educational Research Journal 32(1): $185-223$. 
PARAN, A. 2008. "The role of literature in instructed foreign language learning and teaching: An evidence-based survey." Language Teaching 41/4: 465-496.

Parkinson, B. And Reid T. H. 2000. Teaching Literature in a Second Language. Edinburgh: Edinburgh University Press.

SÁnchez, P. 2008. The use of literature with different language levels. English Text Construction. 1, 2, 226-238.

SAvvidou, C. 2004. An Integrated Approach to Teaching Literature in the EFL Classroom. The Internet TESL Journal, Vol. X, No. 12, December 2004.

SchAEFFER, B. 1982. Linguistic Functions and Language Intervention: Part I. Concepts, Evidence and Instructional Sequence. The Journal of Spaecial Education, 16, 3, 289-308.

SCHRÖDER, K. ed. 1977. Literatur im fremdsprachenunterricht. Diesterweg: Frankfurt.

Short, M. 1996. Exploring the Language of Poems, Plays and Prose. London: Longman.

Short, M. H., AND CANDlin, C. N. 1986. Teaching study skills for English literature. In C. J. Brumfit and R. A. Carter eds., Literature and Language Teaching (pp. 89-109). Oxford: Oxford University Press.

Thanasoulas, D. 1999. “Course Book, Take It or Leave It”. [Online] Available: http:// www.tefl.net/esl-articles/coursebook.htm (February 10, 2010).

Van Ek, J.A., And Alexander, L.G. 1975. Threshold Level English. Oxford: Pergamon Press.

VANDRICK, S. 2003. Literature in the teaching of second language composition. In B. Kroll ed., Exploring the dynamics of second language writing. Cambridge: CUP, 263-283.

Widdowson, H.G. 1992. Practical Stylistics. Oxford: OUP.

WILKINS, D. 1972. Grammatical, situational and notional syllabuses. In Association Internationale de Linguistique Appliqueé ed.. Proceedings of the $3^{\text {rd }}$ International Congress of Appied Linguistics. Heidelberg: Julius Groose Verlag. 